\title{
Filsafat, Teologi dan Pemajuan Kebudayaan
}

\author{
Paul Richard Renwarin \\ Sekolah Tinggi Filsafat Seminari Pineleng \\ renca_p@yahoo.com
}

\begin{abstract}
This article deals with the kern question, "what can the philosophy and theology contribute to develop the culture, as the Indonesian law number 15 on the year of 2017 challenges?" Answering this question, I look for the conception of culture, the core elaboration of philosophy and theology, and their methods of research. The meeting point of the trio is the human experience; both philosophy and theology concern of the inner and deeper side of human experience, i.e. beliefs, values, and fundamental assumptions of life.
\end{abstract}

\section{Keywords:}

Pemajuan Kebudayaan, Filsafat, Berteologi Kontekstual, Metode Penelitian, Kebudayaan Indonesia.

\section{PENDAHULUAN}

“Dalam rangka perayaan 50 tahun, Sekolah Tinggi Filsafat Seminari Pineleng (STFSP) sebagai institusi akademik yang mengkhususkan diri pada kajian Filsafat dan Teologi hendak berefleksi tentang peranan Filsafat dan Teologi bagi pembangunan masyarakat. STFSP berhadapan dengan tantangan sekaligus juga peluang baru untuk membuat kajian Filsafat dan Teologi aktual dan kontekstual dalam menjawab dan memberikan solusi bagi persoalan-persoalan publik. STFSP ditantang untuk mengembangkan penelitian dan kajian spesifik filsafat dan teologi, dan lebih lanjut memanfaatkan hasil kajian tersebut bagi usaha pengembangan kesejahteraan masyarakat, salah satunya dalam bidang pemajuan kebudayaan". Demikian pembukaan term of reference untuk seminar kebudayaan dalam rangka perayaan 50 tahun STFSP ini.

Dalam bahasan ini saya akan menelisik upaya pemajuan kebudayaan, yang menantang bidang ilmu Filsafat dan Teologi untuk berkontribusi. Undang- 
undang Republik Indonesia No. 5 tahun 2017 tentang Pemajuan Kebudayaan memberikan rambu-rambu jalan untuk menuntun kegiatan pengembangan kebudayaan itu, sementara dalam khasanah ilmu Filsafat dan ilmu Teologi sudah lama bergaung kecenderungan untuk "berfilsafat dalam konteks" (doing philosophy in context) ${ }^{1}$ dan "berteologi kontekstual" (doing contextual theology)2.

\section{METODE}

Tulisan ini menggunakan corak penelitian deskriptif dengan metode penelitian kualitatif. Sedangkan, teknik pengolahan data yang dipakai di sini adalah literature review (tinjauan kepustakaan).

\section{HASIL DAN PEMBAHASAN}

\section{Upaya Pemajuan Kebudayaan}

Setelah melewati diskusi-diskusi yang panjang dan bersemangat selama bertahun-tahun, akhirnya tersusunlah suatu undang-undang tentang pemajuan kebudayaan di Indonesia, yaitu UU no. 5 tahun 2017. Dalam Bab I pasal 1 juncto 1 tertera rumusan yang sangat singkat tentang kebudayaan itu, yakni "kebudayaan adalah segala sesuatu yang berkaitan dengan cipta, rasa, karsa, dan hasil karya masyarakat"; juncto 2, "kebudayaan nasional Indonesia adalah keseluruhan proses dan hasil interaksi antar-kebudayaan yang hidup dan berkembang di Indonesia", sementara juncto 3 menegaskan bahwa "pemajuan kebudayaan adalah upaya meningkatkan ketahanan budaya dan kontribusi budaya Indonesia di tengah peradaban dunia melalui perlindungan, pengembangan, pemanfaatan, dan pembinaan kebudayaan".

Dalam penjelasanumum dariUUNo.5tahun2017initercantumasas pemajuan Kebudayaan Nasional Indonesia ini yaitu “.. toleransi, keberagaman, kelokalan, lintas wilayah, partisipatif, manfaat, keberlanjutan, kebebasan bereskpresi, keterpaduan, kesederajatan, dan gotong royong" (pasal 3). Sementara tujuan pemajuan Kebudayaan Na sional ini ialah “.. untuk mengembangkan nilai-nilai luhur budaya bangsa, memperkaya keberagaman budaya, memperteguh jati diri bangsa, memperteguh persatuan dan kesatuan bangsa, meningkatkan citra bangsa, mewujudkan masyarakat madani, meningkatkan kesejahteraan rakyat, melestarikan warisan budaya bangsa, dan mempengaruhi peradaban dunia, sehingga Kebudayaan menjadi haluan pembangunan nasional" (pasal 4).

\footnotetext{
${ }^{1}$ Bdk. Magnis Suseno, Berfilsafat dalam Konteks (Jakarta : PT. Gramedia Pustaka Utama, 1992).

${ }^{2}$ Bdk. P.R. Renwarin, Upaya Berteologi Kontekstual (Pineleng: Percikan Hati, 2020).
} 
Rumusan singkat yang dipakai dalam undang-undang ini menyiratkan adanya tiga batasan pemahaman tentang apa itu kebudayaan. Yang pertama, kebudayaan itu dirumuskan sebagai kata benda, yaitu "hasil karya manusia" atau "artefact", yang meliputi: tradisi lisan, manuskrip, adat-istiadat, ritus, pengetahuan tradisional, teknologi tradisional, seni, bahasa, permainan rakyat, dan olah raga tradisional (pasal 5). Yang kedua, kebudayaan dirumuskan sebagai kata kerja, yaitu "segala sesuatu yang berkaitan dengan cipta, rasa, dan karsa", yang merujuk kepada tindakan dan tingkah laku (human act, behavior) yang berlangsung dan dialami nyata. ${ }^{3}$ Sedangkan paham yang ketiga ialah kebudayaan sebagai strategi, sebagaimana terungkap dalam upaya "pemajuan" kebudayaan. Dan merujuk kepada pemikiran C.A. van Peursen", Poespowardojo ${ }^{5}$ menjelaskan,

Kebudayaan adalah suatu proses yang perlu dikelola dan diarahkan. Di sini manusia secara sadar mencoba mencampuri perkembangan kebudayaan agar berjalan sesuai dengan apa yang dianggapnya sebagai bermakna dan baik. Dalam kebudayaan, manusia tidak hanya berusaha mengidentifikasi bagaimana sifat sesuatu, melainkan menentukan bagaimana seharusnya sifat sesuatu atau perbuatan yang dilakukan. Dengan demikian proses kebudayaan berjalan dalam suatu ketegangan antara gelombang fakta-fakta yang mengurung manusia dalam keniscayaan alam dan ide atau norma yang hendak dicapai, antara imanensi dan transendensi. Untuk itu perlu dilakukan refleksi kritis atas kenyataan untuk dapat memberikan evaluasi yang tepat. Dengan demikian, kebudayaan adalah penilaian terhadap proses perkembangannya sendiri dengan membuka jalan baru, menjalankan pembaharuan dan perbaikan kehidupan masyarakat.

\section{Menelusuri Kebudayaan}

Penelusuran kebudayaan itu dapat dibandingkan dengan menelusuri lautan. Pada tataran permukaan, seraya bermain di atas ombak dan gelombang, kita dapat mengamati artefak-artefak, ritual-ritual dan tindakan-tindakan. Semua ini menyajikan petunjuk-petunjuk tentang apa saja yang terdapat di bawahnya. Tetapi untuk membenarkan ini, kita harus menyelam ke bawah. Ini berarti me-

\footnotetext{
${ }^{3}$ Bdk. Soerjanto Pooespowardojo, Strategi Kebudayaan. Suatu Pendekatan Filosofis (Jakarta: PT. Gramedia Pustaka Utama, 1993), hal. 64.

${ }^{4}$ Bdk. C. A. van Peursen, Strategi Kebudayaan, terj. Dick Hartoko (Jakarta: BPK Gunung Mulia, 1976).

${ }^{5}$ Bdk. Pooespowardojo, Strategi Kebudayaan, hal. 64-65.
} 
mengajukan pertanyaan-pertanyaan untuk menemukan alasan-alasan: nilainilai (values) dan kepercayaan-kepercayaan(beliefs) yang memberikan penjelasan tentang tindakan-tindakan di atas. Tetapi lebih ke dalam lagi terdapat asumpsiasumpsi mendasar yang sulit untuk dicapai dan perlu diinferensi (ditarik simpulan) lewat interpretasi. Hal ini membutuhkan peralatan yang canggih (interpretasi) untuk menggali harta terpendam, yaitu kekuatan budaya itu. Gambar di bawah ini bisa membantu untuk mendapatkan pengertiannya. ${ }^{6}$

Bila kita meneliti kebudayaan, pendekatan interpretive perlu dipakai untuk mendapatkan maknanya. Pendekatan ini, yang lazim untuk penelitian klinis atau etnografis, mencakup pengamatan yang ekstensif tentang artefak, ritual, serta tindakan dan tingkah laku pada tataran permukaan. Selanjutnya diadakan wawancara untuk mendapatkan deskripsi-deskripsi yang rinci dan kaya tentang tata nilai (values) ${ }^{7}$ dan kepercayaan-kepercayaan (beliefs). Kemudian perlu masuk lebih ke dalam lagi dengan membuat inferensi dan interpretasi terhadap asumsi-asumsi mendasar yang dianut warga; asumsi-asumsi mendasar itu ada kalanya disamakan dengan pandangan dunia (Weltanschauung/worldview), seperti hubungan manusia dengan lingkungan alamnya, relasi antar manusia, kollektivisme versus individualisme, kegiatan manusiawi (being os doing), paham tentang gender (kepriaan vs kewanitaan), paham tentang ruang, waktu dan realitas, kecenderungan untuk ascription vs achievement, dsb. Justru penelusuran lebih ke dalam (inferensi dan interpretasi) dari permukaan realitas kehidupan inilah terdapat titik temu antara kebudayaan, filsafat dan teologi.

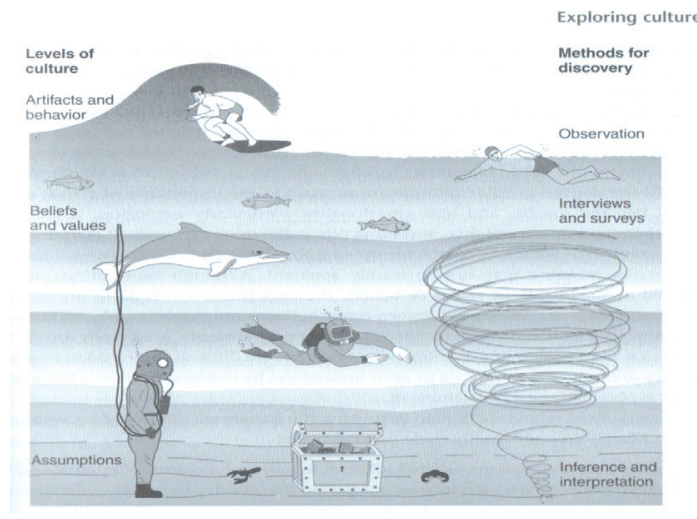

6 Bdk. Susan C Schneider \& Jean-Louis Barsoux, Managing Across Cultures (London: Prentice Hall, 2003), hal. 20-24.

7 Selain nilai-nilai yang sudah disebutkan sehubungan dengan asas pemajuan kebudayaan di atas, Rheinald Kasali memberikan sejumlah nilai karakter yang lasim dianut, yaitu: religius, 
Dalam refleksinya tentang perkembangan kebudayaan dunia, C.A. van Peursen menegaskan bahwa ${ }^{8}$

\begin{abstract}
"kebudayaan jangan dipandang sebagai sebuah titik tamat atau keadaan yang telah tercapai, melainkan terutama sebagai sebuah penunjuk jalan, sebuah tugas: kebudayaan itu ibarat cerita yang belum tamat, yang masih harus disambung, ... sebagai suatu bagian dalam cerita tentang sejarah perkembangan. Kalau kita sudah mengerti bagaimana suatu proses berjalan, maka kita juga dapat mempengaruhi proses tersebut.

Perkembangan historis semata-mata tak pernah diterima oleh manusia begitu saja, melainkan selalu dinilai juga dengan salah satu cara. Penilaian serupa ini kita namakan: evaluasi. Manusia selalu harus mempersoalkan berlaku tidaknya paspor kebudayaan.
\end{abstract}

\title{
Tahap Perkembangan Kebudayaan
}

Van Peursen merujuk pada pendapat Immanuel Kant yaitu bahwa ciri khas kebudayaan terdapat dalam kemampuan manusia untuk mengajar dirinya sendiri: what is dan what should; di sini dalam sikap manusia itu dijumpai ketegangan antara "imanensi" (serba terkurung) dan "transensensi" (yang mengatasi sesuatu, berdiri di luar sesuatu).

Selanjutnya van Peursen melihat tiga tahapan perkembangan kebudayaan yang sudah dan sedang berlangsung. ${ }^{9}$ Tahapan pertama dikategorikannya sebagai TAHAP MITIS, di mana hubungan manusia dengan lingkungan alam dan lingkungan sosialnya dicirikhaskan dan dijelaskan dengan bahasa mitologis yang sudah menerima bahwa segala isi jagad raya "itu ada", masing-masing pada tempatnya dan porsinya. Pada tahapan perkembangan kebudayaan lebih lanjut perhatian sudah diarahkan pada paham substansialisme dengan mendudukkan manusia sebagai subjek yang berhadapan dengan pelbagai objek yang mengisi jagad raya ini; perhatian diarahkan terutama pada pertanyaan dasar: "apa itu?" yang mencaritahu tentang substansi sesuatu; van Peursen menyebut tahapan ini sebagai TAHAP ONTOLOGIS. Tidak dijelaskannya kapan peralihan dari tahap pertama ke tahap kedua itu berlangsung pada suatu

jujur, toleransi, disiplin, kerja keras, kreatif, mandiri, demokratis, rasa ingin tahu, semangat kebangsaan, cinta tanah air, menghargai prestasi, bersahabat-komunikatif, cinta damai, gemar membaca, peduli lingkungan, peduli sosial, dan tanggung jawab. Bdk. Rheinald Kasali, Cracking Value (Jakarta: P.T. Gramedia Pustaka Utama, 2012)

8 Bdk. Peursen, Strategi Kebudayaan, hal. 13-15.

9 Bdk. Ibid., hal. 90-108. 
kebudayaan dan masyarakatnya; ada budaya yang sudah lama memasuki tahap ontologis ini, sedang masih terdapat juga budaya dan masyarakat yang masih berkecimpung pada tahap mitis. Sesudah tahap ontologis kebudayaan itu berkembang memasuki era yang baru, yang disebutnya TAHAP FUNGSIONAL. Lebih lanjut dia menjelaskan bahwa

justru dalam tahap fungsional ini nampak dengan jelas, bahwa kebudayaan bukanlah sebuah kata benda, melainkan sebuah kata kerja. Kebudayaan tak lain dari caranya seorang manusia mengekspresikan diri, caranya ia mencari relasi-relasi tepat terhadap dunia sekitarnya. Kebudayaan khususnya merupakan suatu strategi untuk menyalurkan relasi-relasi itu secara spiritual. Maka dari itu relasi terhadap dunia ilahi selalu dipersoalkan dalam kebudayaan itu. Pun dalam tahap fungsional, walaupun dunia adikodrati sebagai suatu dunia tersendiri, tidak diterima. Dunia ilahi lebih dipandang sebagai suatu dimensi esktra dalam dunia kodrati ini. Pertanyaan mengenai adanya Tuhan diketengahkan secara fungsional: orang bertanya bagaimana nama 'Tuhan' dapat dikongkritkan dalam hubungan sehari-hari. ${ }^{10}$

Juga van Peursen mengamati terjadinya peralihan dalam kegiatan berteologi pada tahap fungsional ini; bukan lagi dogmatik yang dititikberatkan, melainkan eksegese, tafsir Kitab Suci yang berusaha untuk menampilkan kehadiran ilahi di dalam hubungan-hubungan manusia biasa. ${ }^{11}$

\section{Filsafat dan Pemajuan Kebudayaan}

Filsafat: Apa Gunanya?

Dalam artikelnya yang berjudul "Mengapa Filsafat, apa gunanya?", K. Bertens mengutip pernyataan dari Karl Jaspers, "spesialisasi filsafat adalah yang umum"; maksudnya filsafat tidak mempunyai spesialisasi tertentu. ${ }^{12}$ Dalam uraian selanjutnya beliau mengemukakan suatu slogan yang pernah dibacanya (tapi sudah dilupa dari sumber mana) yang berbunyi: "kebudayaan yang sungguh-sungguh hidup tidak mungkin tanpa filsafat". Lalu dia menjelaskan:

${ }^{10}$ Ibid., hal. 105.

${ }^{11}$ Bdk. Ibid., hal. 108.

${ }^{12}$ Bdk. Kees Bertens, “Apa Itu Filsafat?”, dalam K. Bertens, J. Ohoitimur \& Mikhael Dua, Pengantar Filsafat. Seri Atmajaya 34 (Yogjakarta: Kanisius, 2018), hal. 47. 
Suatu kebudayaan tentu mencakup banyak sekali komponen. Dan dibandingkan dengan komponen-komponen lain, pasti peranan filsafat kecil saja dan amat terbatas. Namun demikian, peranannya tidak bisa ditiadakan tanpa merugikan kebudayaan secara mendalam. Filsafat berkaitan dengan kecenderungan manusia yang tak terelakkan untuk berpikir, bertanya, mempersoalkan. Ia merupakan instansi kritis yang sangat dibutuhkan untuk mendinamisasikan kebudayaan secara keseluruhan. Filsuf berharap bahwa di Indonesia juga tersedia tempat bagi filsafat dalam dunia kultural. Dan harapan ini tidak tanpa dasar... Bukankah filsafat -di samping agama dan kesenian, dan dengan demikian menggenapi triade Hegelian - dapat memberi sumbangan yang berarti dalam memajukan kepentingan spiritual ini? ${ }^{13}$

Bila dilihat gambar di atas tentang menelusuri komponen-komponen kebudayaan, kiranya jelas bahwa filsafat tidak langsung menyoroti artefak, ritual ataupun tindakan-tindakan manusiawi yang kelihatan dalam hidup sehari-hari, melainkan harus masuk lebih ke dalam untuk menyelidiki komponen-komponen yang tak langsung tertangkap panca indera. Woodhouse menegaskan bahwa permasalahan filsafat berkaitan dengan ide-ide dasar, mengenai kebenaran, makna, dan hubungan logis, yang tidak bersifat empiris langsung. ${ }^{14}$ Begitu juga Poespowardojo mengatakan bahwa

Filsafat menggarap aspek-aspek manusia yang tidak langsung kelihatan secara inderawi dan jasmani, namun menggarap aspek-aspek yang menyangkut kegiatan berpikir secara rasional, kritis, dan dari dasar yang paling dalam. Fungsi filsafat merangsang berpikir kritis, menanamkan dan membudayakan sikap terbuka, dan memberi orientasi tingkah laku. ${ }^{15}$

Filsafat adalah disiplin ilmiah yang bertugas membuat kita memahami implikasi-implikasi dari segala gejala yang setiap hari membanjiri kita, agar kita dapat menilainya, mengritiknya, menemukan jarak dan dapat mengambil sikap terhadapnya; demikian penegasan F. Magnis Suseno. ${ }^{16}$ Beliau melanjutkan bahwa filsafat zaman sekarang memang harus bergulat dengan masalah-masa-

${ }^{13}$ Bdk. Bertens, “Apa Itu Filsafat”, hal. 55.

${ }^{14}$ Bdk. Mark B. Woodhouse, Berfilsafat. Sebuah Langkah Awal, terj. Ahmad Norma Permata dan P. Hardono Hadi (Yogjakarta: Kanisius, 2000).

${ }^{15}$ Poespowardojo, Strategi Kebudayaan, hal. 128.

${ }^{16}$ Bdk. F. Magnis Suseno, Berfilsafat dalam Konteks (Jakarta: P.T. Gramedia Pustaka Utama, 1992) hal. 6-8. 
lah dalam masyarakat sekarang. Harus membuat kita melihat dengan tajam dan kritis apa yang terjadi di sekeliling kita, di mana kita mau tak mau tersangkut. Kegiatan berfilsafat dalam konteks ditantang agar

a) Filsafat secara kritis harus menyertai ilmu-ilmu sosial dalam sikap mereka terhadap kompleks masalah hubungan antara individu, institusi, dan ideologi;

b) Secara khusus filsafat dapat membantu untuk merefleksikan kembali kedudukan agama di dalam kompleks itu tadi, dan sekaligus menjadi basis bagi dialog antar agama;

c) Filsafat mengupas ideologi-ideologi terkemuka yang menentukan iklim nasional dan internasional seperti: kapitalisme, marxisme, komunisme, sosialisme, elitarisme, pragmatisme, kepercayaan kepada teknologi, ideologi tentang kemajuan dan lain-lainnya.

Sebagai ilmu kritis filsafat memungkinkan masyarakat memikirkan masalahmasalah dasar hidupnya secara rasional, jadi dengan bahasa, wawasan, dan argumentasi yang universal, yang dapat dimengerti oleh semua. Dengan demikian filsafat membuka cakrawala bagi diskusi terbuka masalah-masalah yang dihadapi dan sekaligus membuat kita jeli terhadap penyempitanpenyempitan ideologis; demikian penegasan F. Magnis Suseno. ${ }^{17}$ Secara khusus beliau membahas tentang kegiatan berfilsafat di Indonesia, yakni

Di Indonesia itu juga berarti bahwa filsafat membantu kita mengambil jarak terhadap 'claim' ideologis ilmu-ilmu empiris bahwa dalam budaya modern ilmu-ilmu empirislah yang mendefinisikan arti kemanusiaan dan tujuan perkembangan masyarakat. Filsafat dapat membantu dalam mengambil sikap terbuka dan kritis terhadap dampak modernisasi, memungkinkan kita untuk berhadapan dengan meluasnya budaya modern yang memang tak terbendung, mengambil sikap dan menjadi pemain aktif, mempertahankan identitas kita, mengusulkan perkembangan sesuai dengan pandangan kita sendiri. Filsafat membantu menggali kebudayaan, tradisi-tradisi dan filsafat Indonesia asli secara terbuka, kritis, dan kreatif...

Filsafat dapat mendeteksi kedok-kedok ideologis pelbagai ketidakadilan sosial serta pelanggaran-pelanggaran terhadap martabat manusia dan hak-

${ }^{17}$ Bdk. F. Magnis Suseno, Filsafat sebagai Ilmu Kritis (Yogjakarta: Kanisius, 1992), hal. 254-256. 
hak asasinya. Filsafat memungkinkan orang dari pandangan dunia dan agama yang berbeda untuk bersama-sama membahas tantangan-tantangan yang dihadapi bangsa serta untuk mencari pemecahan yang berorientasi pada martabat manusia.

\section{Model Penelitian Filsafat}

Bidang yang menjadi obyek penelitian filsafat menurut filsuf Inggris Alfred North Whitehead ialah pengalaman, yang digambarkannya mirip dengan gambar bidang penelitian kebudayaan yang tertera di atas. J. Sudarminta SJ secara ringkas menyajikan paham dari Whitehead ini dalam artikelnya yang berjudul "Model penelitian filsafat menurut Whitehead". ${ }^{18}$ Ditegaskannya bahwa prinsip metodis pertama dalam penelitian filsafat menurut model Whitehead adalah menjadikan pengalaman sebagai sumber dan muara penelitian filsafat. Kekhasan penelitian filsafat ini terletak pada pengertian pengalaman itu sendiri dan macam generalisasi imaginatif yang dicoba untuk dirumuskannya. Yang dimaksudkan dengan pengalaman itu oleh Whitehead bukan hanya apa yang dapat dicerap oleh panca indera manusiawi, tetapi mencakup seluruh realitas yang ada sejauh dapat dialami, dipikirkan, dan direfleksikan oleh akal budi manusia. Itu berarti seluruh kenyataan yang terlibat dalam proses terbentuknya apa yang disebut Whitehead actual entities, yaitu entitas-entitas aktual sebagai gumpalan atau satuan pengalaman yang memadarkan secara perspektival seluruh kenyataan yang ada. Lebih lanjut Sudarminta menerangkan bahwa ${ }^{19}$

Radikalitas empirisme Whitehead secara eksplisit terungkap dalam teori persepsinya yang dia sebut capital efficacy atau causal prehension yang merupakan bentuk pencerapan secara paling dasariah atas dunia sekitar. Whitehead membedakan tiga jenis persepsi. Persepsi berdasarkan pencerapan panca indera, yang oleh Whitehead disebut persepsi dalam bentuk presentational immediacy, hanyalah salah satu bentuk dari ketiga jenis yang ada. Yang dialami melalui persepsi dalam bentuk presentational immediacy tidak lain hanyalah apa yang secara langsung tampak atau menyediakan diri bagi panca indera manusia. Empirisme Inggeris menyamakan persepsi dengan persepsi inderawi atau presentational immediacy. Padahal, menurut

\footnotetext{
${ }^{18}$ Bdk. J. Sudarminta SJ, "Model penelitian filsafat menurut Whitehead". Majalah Filsafat Driyarkara. Pemikiran proses. Tahun xxi no.1, 1994/1995.

${ }^{19}$ Bdk. Ibid., hal. 6-10.
} 
Whitehead, jenis persepsi ini sudah merupakan suatu abstraksi dari jenis persepsi yang lebih dasariah, yakni persepsi dalam bentuk causal efficacy. Dalam persepsi macam ini, di mana objek menyatakan diri dan ditangkap oleh subjek yang mencerapkannya, objek menyatakan diri dan ditangkap oleh subjek masih dalam keutuhannya dengan segala kekaburan dan kompleksitasnya serta belum terdiferensiasi secara jelas dan tegas.

Jenis persepsi yang ketiga oleh Whitehead disebut persepsi dalam bentuk symbolic reference atau symbolic transference. Jenis persepsi ini adalah persepsi yang lazim kita mengerti, dan merupakan perpaduan antara persepsi dalam bentuk causal efficacy dan presentational immediacy. ${ }^{20}$

Whitehead berpendapat pengalaman itu selalu jauh lebih kaya dari pengetahuan. Kalau kenyataan disamakan dengan apa yang dapat diketahui oleh manusia dan yang dapat diketahui secara lebih sempit lagi disamakan dengan apa yang tentangnya manusia dapat membuktikan gagasan yang jelas dan tegas, maka kenyataan akan adanya Yang Ilahi, adanya nilai-nilai, adanya arah, makna dan tujuan hidup yang secara objektif dialami manusia lalu tersingkir atau dianggp sebagai gejala subjektif belaka.

Dalam filsafat prosesnya, Whitehead berpendapat bahwa manusia dapat berkembang subur dalam tahap-tahap hidup yang rendah melulu dengan cercah-cercah sinar pemikiran yang masih primitif. Akan tetapi pada waktu peradaban sudah mencapai puncaknya, tidak adanya suatu filsafat hidup yang mempersatukan dan tersebar ke seluruh warga masyarakat, akan mengakibatkan kemerosotan, kejenuhan dan kelesuan usaha. ${ }^{21}$

Tentang tugas filsafat menurut Whitehead, sebagaimana diringkas oleh Sudarminta, yaitu dari hakekatnya sebagai usaha rasional menemukan arti dan

${ }^{20}$ Dalam catatan kaki nomor 7 di artikelnya Sudarminta memberikan contoh tentang pengalaman terhadap sebuah meja: "pengalaman saya sekarang berhadapan dengan benda padat, persegi empat, berkaki empat dan berwarna coklat, membuat saya menyadari dan membuat pernyataan 'ini sebuah meja'. Kesadaran dan pernyataan tersebut tidak hanya saya dasarkan atas pengalaman inderawi saya (baik itu menyangkut warna, bentuk bau, halus/ kasarnya benda, dsb.), tetapi juga mengandaikan seluruh pengalaman masa lalu, baik dari benda di hadapan saya maupun dari saya sendiri. Kata 'meja' merupakan simbol linguistis yang menunjuk (mereferensi) pada realitas tertentu yang saya alami di hadapan saya. Bahwa kata 'meja' merupakan simbol linguistis yang menunjuk pada realitas sebagaimana saya hadapi sekarang, itu juga merupakan warisan sosio-budaya (bahasa) saya. Dalam lingkungan sosio-budaya lain, realitas yang sama disebut dengan kata yang berbeda. Demikianlah masa lalu beserta lingkungan hidup langsung saya dan orang yang saya ajak berkomunikasi ikut terlibat dalam pernyataan di atas. Begitu pula masa lalu beserta lingkungan hidup langsung benda yang saya sebut 'meja' itu, karena tidak semua benda yang saya sebut 'meja' adalah persis sama dengan meja yang saya maksudkan". Bdk. Ibid, hal. 7.

${ }^{21}$ Bdk. Ibid, hal. 10. 
makna yang dalam dari seluruh aspek pengalaman manusia atau mencari penjelasan tentang keseluruhan kenyataan guna memperoleh kebijaksanaan hidup, sekaligus mempunyai fungsi kritis-evaluatif terhadap macam-macam pengetahuan yang diberikan oleh ilmu-ilmu lain. ${ }^{22}$

\section{Mengarah ke Peradaban}

Filsafat berperan penting dan khas untuk memajukan kebudayaan atau peradaban. Salah satu filsuf yang saya temukan dan sudah merumuskan secara rinci tentang cita-cita masyarakat yang beradab itu ialah Alfred North Whitehead; karena itu saya mencoba untuk memaparkan pandangannya secara lebih panjang di sini. Tentang peradaban secara tentatif Whitehead menyatakan bahwa peradaban pada dasarnya merupakan suatu proses ke arah pencapaian suatu ideal hidup tertentu di bumi ini, ideal hidup yang menyangkut masingmasing pribadi maupun masyarakat. Sebagai suatu usaha untuk merumuskan sifat-sifat yang mencirikan masyarakat yang beradab atau berbudaya, Whitehead menunjukkan 5 hal, yakni: kebenaran, keindahan, sikap bertualang, seni dan kedamaian batin; 5 hal ini tercemin dalam masyarakat yang beradab. Sudarminta sudah meringkas paham filsafat proses dari Whitehead ini, dan tentang 5 hal penanda masyarakat beradab itu dapat diringkaskan demikian: ${ }^{23}$

a) Kebenaran ialah kesesuaian antara penampilan luar dengan kenyataan (the conformation of appearance to reality). Masyarakat yang beradab itu secara kreatif sanggup hidup sesuai dengan jati dirinya dan mampu menampilkan apa yang sesuai dengan kenyataan dirinya.

b) Keindahan: keindahan itu lebih luas dan lebih dasariah daripada "kebenaran" (beauty is wider and more fundamental than truth). "Keindahan" dia mengerti sebagai saling penyesuaian beberapa fakta dalam suatu kejadian pengalaman (the mutual adaptation of several factors in an occasion of experience). Wilayah keindahan adalah "forma" subjektif atau bagaimana si subjek mengalami lingkungannya; ada keindahan "mayor" dan "minor", contohnya patung-patung di gereja Chartres di Paris.

c) Masyarakat yang beradab menghayati nilai "seni". "Seni" sebagai usaha untuk secara sengaja menyesuaikan penampilan luar atau apa yang tampil dengan kenyataan ("art" is purposeful adaptation of appearance to reality). Tu-

${ }^{22}$ Bdk. Ibid., hal. 12.

${ }^{23}$ J. Sudarminta SJ, Filsafat Proses. Sebuah pengantar sistematik filsafat Alfred North Whitehead. Edisi ke-2 (Yogjakarta: Kanisius, 1994). 
juan karya seni adalah keindahan yang benar (truthful beauty); keindahan yang didasarkan atas kenyataan. Dalam bidang seni ini terdapat pula nilai kebebasan, tetapi kebebasan itu selalu yang bersituasi; "sekedar menuntut kebebasan tanpa batasan apa-apa adalah perkara filsafat yang dangkal, sama bahayanya dengan seruan yang sebaliknya untuk menyesuaikan diri dengan pola yang sudah baku" (a mere unqualified demand for liberty is the issue of shallow philosophy, equally noxious with the antithetical cry for mere conformation to standard pattern).

d) Salah satu sumbangan "seni" pada masyarakat adalah sifatnya yang spontan dan berani bertualang (spontaneity and adventurousness). Sikap avonturir (keberanian untuk mencoba yang baru) mesti menandai juga suatu masyarakat yang beradab. "Tanpa adanya sikap bertualang, peradaban akan merosot dan runtuh" (without adventure, civilization is in full decay). "Suatu bangsa mempertahankan gairah kekuatannya sejauh mengandung kontras yang sejati antara apa yang sudah terjadi dan apa yang mungkin; dan sejauh bangsa itu digerakkan oleh gairah kekuatannya untuk bertualang melewati batas-batas keamanan masa lampau" (a race preserves its vigour so long as it harbours a real contrast between what has been and what may be; and so long as it is nerved by the vigour to adventure beyond the safety of the past). Juga modifikasi pola-pola yang sudah ada tidak kalah penting dari usaha untuk melestarikan tradisi. Begitu pula "kemajuan atau kemunduran hanyalah dua kemungkinan yang ditawarkan pada umat manusia. Sikap konservatif murni itu sama saja dengan memerangi hakikat alam semesta" (advance or decadence are the only choices offered to mankind. The pure conservative is fighting against the essence of the universe).

e) Peace ("kedamaian batin" atau "rasa damai yang mendalam"). Peace yang Whitehead maksudkan itu in a way seeking for the notion of Harmony of Harmonies, which shall bind together the other four qualities (yaitu: kebenaran, keindahan, seni, dan petualangan), so to exclude from our notion of civilization the restless egotism with which they have often in fact been pursued. Tanpa kedamaian batin atau rasa damai yang mendalam, pengejaran keempat nilai di atas bisa kasar, keras, kejam, sehingga dengan demikian kehilangan sifat hakiki keberadaannya. "Rasa damai" menyebabkan tidak dikecilkan hatinya oleh kegagalan-kegagalan dan oleh tantangan-tantangan untuk mengusahakan kebaikan.

Masyarakat yang beradab dalam pemikiran Whitehead juga ditandai dengan hal-hal berikut ini:

1) Sikap penghargaan pada individu; 
2) sikap toleran pada sesama warga masyarakat;

3) lebih berperannya persuasi akal daripada kekuatan fisik dalam menyelesaikan masalah;

4) dan terjaminnya pendidikan bagi para warganya.

Nilai suatu sistem sosial tergantung dari pengalaman nilai yang bisa digalang di antara masing-masing pribadi manusia. Kalau manusia sepenuhnya dikebawahkan pada kehidupan kebersamaan, ia akan kerdil.

Sebagai satu catatan akhir bahasan filsafat itu ingin saya ditunjukkan salah satu contoh pemajuan kebudayaan atau perubahan tingkah laku, yang dipicu oleh penerapan nilai karakter (spritualitas) yang baru dalam kegiatan suatu perusahan nasional, seperti ditunjukkan oleh Rheinald Kasali dalam bukunya Cracking Value. ${ }^{24}$ Pada waktu Karen Agustiawan diangkat menjadi direktur utama P.T. Pertamina, beliau membuat perubahan cara kerja dengan mengetrapkan nilai hormat dan pelayanan untuk menjadi budaya atau habitus dari seluruh karyawan Pertamina, sampai pada tingkat SPBU. Dan selama masa kepemimpinannya di Pertamina (tahun 2009-2014) perubahan cara kerja dan suasana di korporasi ini sangat terasa dan juga berpengaruh pada laba penghasilan yang diperolehnya.

\section{Teologi dan Pemajuan Kebudayaan}

Tahap Perkembangan Berteologi

Bila perkembangan kebudayaan dicirikhaskan oleh van Peursen dengan tiga tahapan (mitis, ontologis, dan fungsional), perkembangan (ber-) teologi juga dapat dicirikhaskan dengan tiga tahap, yaitu: tahap teologi monastik, teologi skolastik, dan teologi kontekstual-inkulturasi.

Bila teologi diartikan dalam faham lebih klasik dan lebih sempit lagi, sebagai pencarian Allah, analisa kesanggupan manusia untuk mengenal dan menyelami misteri Allah, rahasia Tritunggal dari Allah yang esa, Kristologi dan Pneumatologi, maka teologi akan menghasilkan suatu faham teo-sentris yang serentak lebih dogmatis, yang mengedepankan iman teolog sendiri ketimbang rasionalitas umum. Ini bisa disebut TEOLOGI MONASTIK, yang laris sampai dengan penerobosan teologi skolastik. Teologi Monastik merenung dan mengenyam misteri Allah melalui lectio divina (baca Kitab Suci), daya kagum

${ }^{24}$ Bdk. Kasali, Cracking Value. 
dan eksplorasi "sanubari Allah" (1 Kor 2:10). Usaha berteologi adalah upaya rohaniwan (yang umumnya hidup di biara atau di pertapaan monastik) lebih daripada upaya ilmuwan. Teologi kontekstual demikian ini menjurus kepada samadi, permenungan dan citarasa mengenyam kebaikan; lebih mistiklah. Trend ini pernah digandrungi pada dasawarsa 1970-an dan 1980-an pada metode berteologi dalam tradisi Timur di Indonesia (bdk. Munculnya buku Ragawidya, Samadi, dsb.). Buku-buku teologi dari Bapa-bapa Gereja atau Patristik menjadi warisan metode Teologi Monastik ini, namun gemanya sudah menghilang dari kegiatan berteologi di banyak STFT.

Teologi sebagai fides quaerens intellectum (iman yang mencari pembuktian akal budi, suatu adagium dari St. Anselmus) mencakup beberapa unsur dari program berteologi sejak abad pertengahan. Dua unsur yang menonjol adalah wahyu dan rasionalitas. Dengan bersandar pada definisi klasik Anselmus ini, teologi mau mengupayakan rasionalitas berdasarkan filsafat setempat. Konteks budaya, konfigurasi nilai-nilai sosial, fenomenologi agama, etnologi suku bangsa setempat, semuanya mau mendapat perhatian untuk dilacaki dan digali. TEOLOGI SISTEMATIKA yang dijodohkan dengan filsafat, khususnya filsafat Yunani, menjadi batu sendi seluruh urusan berteologi (kontekstual). ${ }^{25}$ Inilah TEOLOGI SKOLASTIK yang masih berpengaruh sangat kuat sampai masa kini pada lembaga gereja dan STFT berdasarkan tradisi berteologi Barat. Dengan berdirinya universitas (sejak abad 12) teologi menjadi mata kuliah perguruan tinggi (schola) dan ilmu Filsafat (barat) selalu diajarkan mendahului ilmu Teologi (sebagai 'hamba teologi', ancilla theologica) dan ini masih nampak pada nama: Sekolah Tinggi Filsafat dan Teologi.

Sesudah Konsili Vatikan ke II teologi menjurus kepada jawaban atas kritik masa pencerahan: "agama berguna bagaimana?" Semua teologi mesti menjawab kebutuhan ini, apalagi di seminari dan sekolah tinggi gerejawi. Istilah TEOLOGI PASTORAL muncul dan mencakup pelbagai makna dan arti, akan tetapi bisa dikedepankan "hasil guna" sebagai suatu benang merah di dalamnya. ${ }^{26}$ "Pastoral" bisa diartikan secara sempit -berkisar pada pastor dan

${ }^{25}$ Ini sejajar dengan perkembangan kebudayaan yang berada pada Tahap Ontologis, menurut van Peursen, seperti yang sudah dijelaskan pada nomor 7 di atas. Paham substansialisme sangat kuat berpengaruh.

${ }^{26}$ Ini sejajar dengan Tahap Fungsional dalam perkembangan filsafat dan peradaban, menurut van Peursen. Pertanyaan yang diajukan terutama ialah: 'bagaimana...?' 
tugas pelayanan pejabat-pejabat gerejawi- atau secara luas mencakup seluruh misi gereja, termasuk dan terlebih perutusan kaum awam, sehingga peran pastoral gereja mencakup sentuhan gereja dengan dunia (ekonomi, politik, pendidikan, kesehatan, dsb.). Ada beberapa nama yang lasim juga dipakai seperti: TEOLOGI KONTEKSTUAL dan TEOLOGI INKULTURASI, yang juga berorientasi sama seperti Teologi "Pastoral".

Bila di atas ini disampaikan arah dasar berteologi kontekstual dalam lintasan sejarah dengan menunjuk pada ilmu bantu lainnya yang dipakai, dalam nomor ini akan dibahas perkembangan pendekatan penalaran yang mempengaruhi kegiatan berteologi. Ada dua tahap yang memberikan suatu penataan fundamental bagi semua kegiatan berteologi, yaitu kegiatan "mendengarkan" apa yang dikatakan sumber-sumber, dan "mendengarkan" makna yang terkandung di dalamnya. Hasrat seorang teolog ialah memberi makna. Lewat panggilannya, seorang teolog menjajaki makna apa yang diberikan oleh mereka yang percaya. Pada akhirnya, teologi adalah tentang pemaknaan Sabda Allah yang disampaikan kepada segenap umat manusia, Sabda, yang kaum beriman terima dan coba dengan pelbagai tingkat kesuksesan untuk menghidupinya. Dengan demikian teolog menjadi seorang peneliti tentang pemaknaan Sabda Allah dan kehidupan iman. Hal ini sejajar dengan ungkapan Claude Geffré, dalam edisi khusus Concilium tentang Humanism in question, bahwa

In so far as theologians aim to remain faithful to the words of God today, their task is always new. The theology is a creative renewal of Christian message in the service of man and the question he asks. It is the sphere within which dialogue takes place between Christianity and society. It is clear from the whole history of theology that what is often taken for a confrontation between the Christian message per se and a changed society is in many cases only a conflict between an historically conditioned expression of Christianity and that society. ${ }^{27}$

Konsili Vatikan II (1965) menyampaikan empat dorongan yang relevan untuk suatu metode berteologi, yaitu: 1) untuk merumuskan kembali patrimoni doktrinal agar itu dapat membawa keuntungan-keuntungan menyelamatkan bagi umat manusia; 2) pemahaman yang baru dari Konsili terhadap sumber-

${ }^{27}$ Bdk. Claude Geffre, "The Crisis of Humanism and The Future of Theology". Concilium. Humanism in Question (June, 1973), hal. 7. 
sumber logis: Tradisi dan Kitab Suci, dan dari magisterium gereja; 3) penyertaan historisitas eksposisi-eksposisi doctrinal; dan 4) pembuatan struktur ajaranajaran khusus sesuai dengan "hirarki kebenaran-kebenaran" di dalam iman akan Yesus Kristus.

\section{Metode Berteologi Kontekstual}

Dengan berpatokan pada kecenderungan pascaVatikan II yang mengajukan pertanyaan dasar: "agama berguna bagaimana?", penelitian teologi diarahkan pada kegiatan BER-Teologi. ${ }^{28}$ Berbeda dengan Teologi Skolastik-sistematik, pertanyaan dasar yang diajukan dalam Berteologi ini ialah: "how to". Dan locus berteologi yang paling mendasar ialah pengalaman manusia dalam lingkup kehidupannya (atau kebudayaannya) dan pada masanya, baik pengalaman umat beriman di sini dan kini maupun pengalaman iman yang terungkap dalam khasanah kekayaan teologi gereja yang terekam dalam Kitab Suci, tradisi, dan ajaran-ajaran resmi yang terdokumentasi.

Dengan mengambil pengalaman manusia ini, maka penelitian berteologi ini lebih memakai metode komparasi. Yang dibandingkan ialah dua pihak, yakni: pengalaman hidup beriman manusia dalam konteks sini dan kini, dan hasil pergumulan iman sejak masa Abraham, Yesus dan para Rasul (yang tertera dalam Kitab Suci), Bapa-bapa Gereja, tradisi dan ajaran gereja, atau dengan kata lain isi khasanah teologi. Secara skematis bisa digambarkan demikian:

\begin{tabular}{|c|c|c|}
\hline $\begin{array}{c}\text { STATUS QUO: titik } \\
\text { tolak }\end{array}$ & 1 & $\begin{array}{c}\text { STATUS AD QUEM: titik } \\
\text { tuju }\end{array}$ \\
$\begin{array}{c}\text { Pengalaman iman } \\
\text { dalam konteks hidup } \\
\text { sini dan kini }\end{array}$ & 2 & $\begin{array}{c}\text { Khazanah TEOLOGI: KS, } \\
\text { Teologi dan Magisterium }\end{array}$ \\
\hline
\end{tabular}

Pengalaman hidup dalam konteks sini dan kini menjadi titik berangkat (status quo) dalam berteologi, yaitu kegembiraan dan kecemasan hidup, harapan dan tantangan, makna dan nilai yang dihidupi mempunyai sesuatu sumbangan ba-

${ }^{28}$ Bdk. Jose M. de Mesa \& Lode L. Wostyn, Doing Theology. Basic Realities and Processes (Quezon City: Clarentian Publications, 1990). 
gi kesejahteraan hidup ('keselamatan') dan juga mempunyai akar/dasar dari sumber yang sama, yaitu Allah; pengalaman dan pergulatan hidup yang sama dialami oleh komunitas beriman di dalam tradisi Yudeo-Krisitiani. Sedangkan khasanah kekayaan teologi gereja diyakini mampu menghantar manusia menuju masa depan yang gemilang, yang ingin dicapai, yaitu "dunia dan surga yang baru, keselamatan kekal, hidup yang abadi, dsb., dalam Yesus Kristus". Iman akan Allah Tritunggal memberikan dasar bagi pengharapan akan kehidupan yang lebih baik, yang bebas dari penderitaan (dosa), dan mengajak manusia untuk mencintai Allah dan sesamanya secara altruistis.

Dua kutub ini, konteks hidup/budaya dan teologi, ${ }^{29}$ perlu ditelusuri dengan sikap saling menghormati satu sama lain dan kritis. Isu, masalah, pertanyaan, keprihatinan yang dihadapi manusia dalam konteks hidup budayanya merupakan titik berangkat, ketimbang kehidupan di masa depan (eskatalogis) sesudah kematian dan juga diskusi teologis universiter dalam suatu tuturan bahasa yang asing. Isu, pertanyaan, masalah, dan keprihatinan hidup serupa juga dialami manusia dalam tradisi Yudeo-Kristiani, dan ini menjadi cerminan atau refleksi tentang bagaimana mereka sudah mengalami dan memaknai bahwa Allah sudah berada dan bergiat bersama mereka dalam Roh Kudus. Dengan demikian sudah jelas bahwa pendekatan interpretive untuk masuk lebih mendalami kenyataan hidup harian seperti yang ditunjukkan metode penelusuran kebudayaan dalam gambar di atas (nomor 1), yang perlu dipakai untuk berteologi kontekstual ini, dengan memperhatikan pola tujuh dimensi ini: ${ }^{30}$

1) Pandangan dunia - cara memahami dunia;

2) Proses kognitif - cara berpikir

3) Bentuk linguistik - cara mengungkapkan gagasan

4) Pola perilaku - cara bertindak

5) Media komunikasi - cara menyalurkan berita

6) Struktur sosial - cara bergaul

7) Sumber motivasi - cara mengambil keputusan.

\footnotetext{
${ }^{29}$ Hesselgrave \& Rommen dalam model kontekstualisasinya menggunakan tiga corak kebudayaan, yaitu kebudayaan Alkitab, kebudayaan Kristen modern, dan kebudayaan sasaran; sedangkan menurut hemat saya, kebudayaan Alkitab dan kebudayaan Kristen modern itu saling tumpang tindih dan karenanya akan lebih ruwet untuk ditelusuri. Bdk. David Hesselgrave \& Edward Rommen, Kontekstualisasi: Makna, Metode dan Model, terj. Stephen Suleeman. Cetakan Ke-5 (Jakarta: BPK Gunung Mulia, 2006), hal. 239.

${ }^{30}$ Bdk. Hesselgrave \& Rommen, Kontekstualisasi, hal. 242.
} 
Kegiatan berteologi ini bergerak bolak-balik dari dan ke dua kutub ini dalam suatu proses kumulatif yang mengikuti langkah-langkah ini:

OBSERVASI $\longrightarrow$ AKSI $\longrightarrow$ REFLEKSI $\longrightarrow$ REAKSI

Dan kembali lagi sesudah satu periode dibutuhkan

OBSERVASI

AKSI, dst.

Kegiatan berteologi yang bercorak spiral ini selalu berkelanjutan, dengan asumsi bahwa hidup manusia senantiasa bercorak dinamis dan dari waktu ke waktu selalu muncul isu, masalah, keprihatinan yang baru yang menantang dan meminta jawaban serta arah dari teologi, yaitu "bagaimana Roh Allah sedang berkarya dalam penciptaan baru hidup manusia dan dunia ini menuju kepada kesempurnaan dalam Yesus Kristus". Mgr. I. Suharyo meringkaskan secara sederhana langkah-langkah refleksi spiral pastoral ini demikian: ${ }^{31}$ a) memperhatikan keadaan, pandangan kita atau pandangan orang lain; b) mengajukan pertanyaan-pertanyaan kritis terhadap apa yang kita perhatikan itu dari berbagai sudut pandang: historis, sosiologis, psikologis, ekonomi, social, politik, budaya; c) memperhadapkannya dengan tradisi Katolik (Kitab Suci, Ajaran Gereja); d) membawanya ke dalam doa, kontemplasi yang diharapkan dapat menuntun refleksi bergerak menuju aksi, setelah secara pribadi atau bersama-sama melihat atau menemukan kehendak Allah dalam peristiwa dan pengalaman nyata; e) aksi yang terus disertai refleksi; f) keadaan baru yang menjadi awal baru dari spiral pastoral ini.

Kathryn Tanner memberikan contoh kerja berteologi yang memandang Teologi Kristen sebagai satu bagian dari budaya, demikian: ${ }^{32}$

Gordon Kaufman identifies theology as a part of culture simply in order to situate it within a general understanding of the basic tasks and questions that define human life as a quest for meaning. Such an approach thereby conforms with a rather traditional understanding of philosophical theology. Theology becomes a kind of philosophical enterprises in which answer to perennial issues of importance to human beings the world over are sought...

${ }^{31}$ Bdk. Mgr I. Suharyo, "Butir-Butir Gagasan dalam Sepenggal Sejarah Konferensi Waligereja Indonesia". Spektrum, no. 4, 2019, hal.19.

${ }^{32}$ Bdk. Kathryn Tanner, Theories of Culture. A New Agenda For Theology. Guide to Theological Inquiry (Minneapolis: Fortress Press, 1997), hal. 65. 
Approaching Christian theology as a part of culture means, then, correlating the Christian message with human universals, with general structures that are at the bedrock of all human knowing and doing.

\section{Contoh Topik atau Isi Berteologi Kontekstual}

Terdapat suatu pembedaan lain lagi yang perlu dijelaskan di sini tentang kegiatan berteologi. Kathryn Tanner memberikan pembedaan kegiatan berteologi pada tataran akademi dan pada tataran kehidupan harian, demikian: ${ }^{33}$

Theology is often identified with the production of educated elites, such as clergy and academics. When that identification is made, theology is equated with writings in which conceptual precision and logical coherence are at a premium. These writings are produced in primary conversation with other writings of a similar sort, and they tend to be read only by people with the same educational background and institutional support for sustained intellectual pursuits as their author. As such a highly specialized intellectual activity, theology seems irrelevant to the common concerns of most people. Putting theology into the cultural context of a Christian way of life challenges this view of theology; it makes theology much more an integral part of daily life.

Ada kegiatan berteologi untuk kehidupan harian, seperti berkotbah, membuat renungan, surat Gembala Uskup, surat pastoral untuk suatu perayaan liturgisgerejawi, dokumen musyawarah pastoral dan sinode, dsb. Misalnya gagasan tentang Eklesiologi yang hidup dan berkembang dalam sejarah Konferensi Waligereja Indonesia (KWI), yang dirumuskan dengan singkat oleh Mgr. I. Suharyo demikian: ${ }^{34}$

Tanpa mengesampingkan gambaran-gambaran Gereja yang lain, Gereja sebagai pewarta pengharapan yang menghayati spiritualitas inkarnatoris, yang dinamikanya digerakkan dengan spiral pastoral, akan berkembang menjadi Gereja Peristiwa: "Gereja peristiwa bukan suatu konsep pastoral, juga bukan model eklesiologi. Gereja peristiwa adalah orang-orang yang hidup, hidup beriman. Dalam kesetiaan janji dan kasih ilahi, mereka mengingat saudara-saudara mereka, yang di abad Paulus hidup di kota-kota RomaHellenis dan yang di abad keduapuluh hidup di Kalkutta atau di Timor Leste,

${ }^{33}$ Bdk. Tanner, Theories of Culture, hal. 69.

${ }^{34}$ Bdk. Suharyo, "Butir-Butir Gagasan", hal. 21. 
di kamp-kamp pengungsi dan Favellas Sao Paolo; mereka mengingat, tanpa usah menyeragamkan bahasa doa mereka. Gereja peristiwa adalah orang beriman, yang berani dan tidak mengalihkan muka dan hati mereka dari penderitaan saudara-saudara dan yang punya imaginasi untuk menolong"35 Gereja Peristiwa adalah kesimpulan dari gerak pengharapan, yang kreatif, komunikatif dan inklusif. Semoga gerak ini semakin disadari, diyakini, dan terus dikembangkan.

Teologi sebagai suatu kegiatan intelektual yang khusus (=ilmu) sebenarnya mengangkat jenis pertanyaan-pertanyaan yang sama dengan teologi untuk kehidupan harian, tetapi kerap kali dalam suatu cara yang lebih umum dan abstrak. Lebihlagiteologiinimenyelidikinya dengansuatucara yangmendukung sesuai dengan tolok ukur-tolok ukur yang tak langsung berhubungan dengan kemendesakan-kemendesakan dari hidup harian; tolok ukur-tolok ukurnya, yang harus diutamakan, antara lain kejelasannya, sistematika, dan konsistensi pengungkapannya; hal-hal mana yang jarang ditemukan dalam hidup harian dan menjawab kebutuhan-kebutuhan semasa dan setempat. ${ }^{36}$

Tokh, teologi akademik atau sebagai ilmu itu dipanggil dan ditantang untuk berkontribusi bagi pemajuan kebudayaan/peradaban, khususnya di Indonesia sebagai konteks berteologi. Dalam suatu seminar internasional dari para teolog moralis se Indonesia, yang diadakan tahun 1997 di Jogjakarta dan disponsori oleh pater Bernard Kieser SJ dengan keynote speaker Dr. Elisabeth Cahill dari universitas Boston, USA, pater B. Kieser SJ mengajukan pertanyaan kritis ini kepada seluruh hadirin, "setelah seratus tahun Gereja Katolik berada di Indonesia, apakah kontribusi nyata dari teologi moral untuk masyarakat Indonesia?" Menjawab pertanyaan menantang ini, saya (seorang antropolog di tengah para moralis ini) memberikan ide bahwa kontribusi teologi moral Katolik untuk kehidupan masyarakat Indonesia ialah soal atau nilai PERCAYA, yang paling mendalam dibahas dalam teologi moral; alasannya ialah corak berelasi antar manusia satu sama lain dalam masyarakat Indonesia umumnya berlangsung dalam sikap tertutup, saling curiga satu sama lain (termasuk di kalangan kaum keluarga besar). Waktu itu pater Kieser mengerti dan menerima usulan tema ini untuk digarap dalam teologi moral.

\footnotetext{
${ }^{35}$ B. Kieser, "Melawan Fundamentalisme (Teologi) Katolik: Menemukan Gereja yang adalah Peristiwa" dalam Gereja yang Melayani dengan Rendah Hati (Yogyakarta: Kanisius 2009), hlm. 14. ${ }^{36}$ Bdk. Tanner, Theories of Culture, hal. 69.
} 
Selain itu, pada seminar internasional Asosiasi Filsafat dan Teologi di Indonesia (AFTI) di Kentungan, Jogjakarta, tahun 2018, saya mengusulkan topik bahasan untuk teologi di Indonesia yaitu Teologi PERSAHABATAN dengan merujuk teks Yohanes 15: 14-15, “Kamu adalah sahabat-Ku, jikalau kamu berbuat apa yang Kuperintahkan kepadamu. Aku tidak menyebut kamu hamba lagi, sebab hamba tidak tahu apa yang diperbuat oleh tuannya, tetapi Aku menyebut kamu sahabat, karena Aku telah memberitahukan kepada kamu segala sesuatu yang telah Kudengar dari Bapa-Ku". Teologi persahabatan ini merupakan sesuatu yang baru dalam corak berelasi antar warga masyarakat Indonesia, yang sangat kuat terikat dengan relasi kekerabatan atau saudara-bersaudara, seperti dalam motto di Sulawesi Utara 'torang samua basudara'; justru corak berelasi sebagai saudara ini masih bercorak tertutup dan eksklusif dan perlu dibuka serta diperkaya dengan corak persahabatan yang sejati.

\section{KESIMPULAN}

Masyarakat dan budaya Indonesia menantang kita untuk ber-Filsafat dalam konteks dan ber-Teologi Kontekstual, apalagi lewat Undang-undang Nomor 5 tahun 2017 tentang Pemajuan Kebudayaan. Apa jawabmu?

\section{DAFTAR KEPUSTAKAAN}

Bertens, Kees, “Apa itu filsafat?”. Dalam Bertens, K., Ohoitimur J. \& Mikhael

Dua, Pengantar Filsafat. Seri Atmajaya 34. Yogjakarta: Kanisius. , 2018, 1-60.

Geffré, Claude, "The crisis of Humanism and the future of theology". Concilium.

Humanism in question. Burns \& Oates. June 1973, 7-13.

Hesselgrave, David \& Rommen, Edward, Kontekstualisasi: makna, metode dan

model. Terj. oleh Stephen Suleeman. Cetakan ke 5, Jakarta: BPK Gunung Mulia, 2006.

Kasali, Rheinald, Cracking Value. Jakarta: P.T. Gramedia Pustaka Utama, 2012. Kieser, B., "Melawan Fundamentalisme (Teologi) Katolik: Menemukan Gereja yang adalah Peristiwa”. Dalam Gereja yang Melayani dengan Rendah Hati, Yogyakarta: Kanisius, 2009.

Magnis Suseno, F., Berfilsafat dalam konteks. Jakarta: P.T. Gramedia Pustaka Utama, 1992a. , Filsafat sebagai ilmu kritis. Yogjakarta: Kanisius, 1992b.

Mesa, Jose M. de \& Wostyn, Lode L., Doing Theology. Basic realities and processes. Quezon City: Clarentian publications, 1990.

Poespowardojo, Soerjanto, Strategi kebudayaan. Suatu pendekatan filosofis. Jakarta: 
P.T. Gramedia Pustaka Utama, 1993.

Renwarin, P.R., Upaya Berteologi Kontekstual. Pineleng: Percikan Hati, (2020).

Schneider, Susan C. \& Barsoux, Jean-Louis, Managing across cultures. London: Prentice Hall, 2003.

Sudarminta, J. Dr. SJ, Filsafat Proses. Sebuah pengantar sistematik filsafat Alfred North Whitehead. Edisi ke 2. Yogjakarta: Kanisius, 1994.

"Model penelitian filsafat menurut Whitehead". Majalah Filsafat Driyarkara. Pemikiran proses. Tahun xxi no.1, 1994/1995: 4-18.

Sudarminta J. \& Lili Tjahjadi S. P (eds.), Dunia, manusia dan Tuhan. Antologi pencerahan filsafat dan teologi. Pesta 80 tahun P. Louis Leahy SJ. Yogyakarta: Kanisius, 2008.

Suharyo, Ignatius Mgr, "Butir-butir gagasan dalam sepenggal sejarah Konferensi Waligereja Indonesia. Spektrum, No.4 Tahun XLVIII, 2019: 15-21.

Tanner, Kathryn, Theories of culture. A new agenda for theology. Guide to theological inquiry. Minneapolis: Fortress Press, 1997.

Van Peursen, C.A., Strategi Kebudayaan. Terj. Dick Hartoko. Jakarta: BPK Gunung Mulia, 1976.

Woodhouse, Mark B., Berfilsafat. Sebuah langkah awal. Terj. Dari "A preface to philosophy", 1984. Yogjakarta: Kanisius, 2000. 